\title{
Non-Strongyloides rhabditida identified in fecal samples - two case reports: lessons learned from morphological and molecular diagnostic approaches
}

\author{
TERESA STACHURSKA-HAGEN ${ }^{1}$, OLE HARALD JOHNSEN ${ }^{2}$ and \\ LUCY J. ROBERTSON ${ }^{1} *$ \\ ${ }^{1}$ Department of Food Safety and Infection Biology, Norwegian University of Life Sciences (NMBU), PO Box 8146, \\ N-0033 Oslo, Norway \\ ${ }^{2}$ Fredrikstad Dyrehospital, Wilbergjordet 2, N-1605 Fredrikstad, Norway
}

(Received 24 May 2016; revised 18 August 2016; accepted 18 August 2016)

\begin{abstract}
SUMMARY
Nematodes in the order Rhabditida, including species of Strongyloides and Pelodera, may be parasites of domestic animals. In this paper, we describe two apparent cases of rhabditid infections, one in a dog and one in a litter of piglets. The dog infection was originally considered likely to be an infection with Strongyloides, based on superficial morphological examination and PCR results without sequencing. However, more careful morphological analysis and inclusion of several molecular analyses, including sequencing, revealed that an infection with Pelodera sp. was more likely, probably Pelodera pseudoteres. Treatment with fenbendazole and selamectin was apparently successful. Similarly, based on both morphological and molecular analyses the apparent piglet infections were considered most likely to be with Rhabditis spp., possibly Rhabditis axei. The detection of larvae of nematodes in the order Rhabditida in fecal samples, particularly from dogs, may easily be considered as being indicative of Strongyloides infection. Given the zoonotic potential of canine Strongyloides, correct diagnosis is important. However, as illustrated by these two cases, careful morphological examination and measurement, supported by full molecular investigations, including sequencing, are essential in order to avoid this misdiagnosis.
\end{abstract}

Key words: Diagnostics, dog, Pelodera, pig, Rhabditida, Rhabditis, Strongyloides.

\section{INTRODUCTION}

The Order Rhabditida includes a range of nematodes with very diverse lifestyles; members of this order may be parasitic, opportunistic, phoretic, saprophytic or free-living. Some of the different species may employ more than one of these lifestyles (Roberts and Janovy, 2005). Of particular medical and veterinary importance are the threadworms in the genus Strongyloides. This genus contains over 50 species, including Strongyoides ransomi, associated with infections in pigs, Strongyloides westeri, associated with infections in horses, and Strongyloides papillosus associated with infections in cattle and sheep (Roberts and Janovy, 2005). Infections with $S$. ransomi and $S$. westeri are often lactogenic, but may also occur via skin penetration, whereas infections with $S$. papillosus infections usually occur by skin penetration or ingestion. Another species is Strongyloides stercoralis, human threadworm, which is endemic in various tropical and sub-tropical climates, and is also recognized as a parasite of various other mammals, in particular dogs (Dillard et al. 2007). Although Strongyloides

* Corresponding author. Department of Food Safety and Infection Biology, Norwegian University of Life Sciences (NMBU), PO Box 8146, N-0033 Oslo, Norway. E-mail: lucy.robertson@nmbu.no infections are often asymptomatic, they can be associated with diarrhoea. Signs of bronchopneumonia, due to the migration of autoinfective third-stage larvae, may also be observed in some species, in particular S. stercoralis. Thus, when rhabditid larvae are identified in samples that have been sent to a diagnostic Parasitology laboratory for analysis, Strongyloides infections are often foremost in the mind of the diagnostic staff. Due to the zoonotic potential of this infection, the correct diagnosis is particularly important.

The genera Pelodera and Rhabditis are also members of the order Rhabditida, and each genus contains a large number of species with differing lifestyles (Deplazes et al. 2016). Several species are considered to be largely saprophytic, but some are facultative, opportunistic parasites, whereas others appear to have a period of obligate parasitism in their lifecycles.

Among the hosts associated with different Pelodera species are termites (Carta et al. 2010) and rodents (Sudhaus et al. 1987; Casanova et al. 1996). Pelodera strongyloides is of particular veterinary importance and cases of dermatitis due to opportunistic invasion of the skin have been reported widely, particularly in dogs (e.g. Willers, 1970; Saari and Nikander, 2006), but also from other mammals such as sheep (e.g. Ramos et al. 1996),

Parasitology Open (2016), Vol. 2, e14; page 1 of 8 . (C) Cambridge University Press 2016. This is an Open Access article, distributed under the terms of the Creative Commons Attribution licence (http://creativecommons.org/licenses/by/4.0/), which permits unrestricted re-use, distribution, and reproduction in any medium, provided the original work is properly cited. 
horses (e.g. Rashmir-Raven et al. 2000), and several human cases have also been reported (e.g. Jones et al. 1991; Tanaka et al. 2004). Another species of Pelodera, $P$. teres, not only has a saprophytic lifestyle, but also has a known affinity with horses and it has been suggested that it may adapt to a parasitic way of living in the digestive tract of horses, as they frequently occur in fresh, non-contaminated horse feces (Lukeš et al. 1982). However, information on this species in horses is sparse, and therefore its prevalence and relevance are unclear.

In the Rhabditis genus, many species are saprophytic and are found in soil, particularly in association with decomposing organic matter, compost and animal feces. However, some Rhabditis species appear to be associated with opportunistic infections and have been found in human samples in association with diarrhoea (Campos et al. 2002), ear infection (Teschner et al. 2014) and Rhabditis axei infections have been reported from AIDS patients (Meamar et al. 2007). Among animals, Rhabditis infections have been recognized as a cause of bovine external otitis in some tropical countries (Duarte et al. 2001) and R. axei infections have also been reported from a species of porcupine (Rakhshanpour et al. 2012) and poultry (El-Azazy et al. 1988).

In this study, we describe two case reports concerned with apparent infections with rhabditid nematodes in domestic animals in Norway. The first case addresses the identification of a rhabditid nematode isolated from the feces of a dog with respiratory symptoms (case 1). The second case (case 2) is concerned with the identification of another rhabditid nematode from the feces of piglets with diarrhoea. In both cases, the identification was unexpected, and useful lessons were learned regarding morphological and molecular identification of rhabditid nematodes that may be of relevance to others in veterinary parasitology diagnostic laboratories.

\section{MATERIAL AND METHODS}

\section{Case 1}

A 6-year old, female, Norwegian Elkhound was referred to Fredrikstad Animal Hospital due to poor physical performance after hunting. The owner suspected that the symptoms were due to the dog having been kicked by a moose. There was no history of cough, vomiting or diarrhoea. Information about the $\mathrm{dog}$ was obtained directly from the owner. The dog had never been out of Norway, and the Norwegian kennel from which the owner obtained the dog initially is in Brumunddal in Hedmark (thus not situated near the border areas) and does not have a history of importing dogs. The dog had been in some limited contact with other Norwegian dogs during the hunting season, but not with imported dogs or with dogs that had been out of Norway. The owners live near a popular local walking trail to which the dog has regular access. The owners also reported that the dog has a tendency to ingest faces from other dogs.

The referring veterinarian conducted a physical examination, bronchoscopy and the dog was subject to $\mathrm{x}$-ray. Blood smears and bronchoalveolar lavage sediment were examined. A pooled fecal sample (fecal samples collected from three consecutive days by the owner, directly after defecation) was sent for analysis to the Parasitology laboratory at the Norwegian University of Life Sciences (NMBU).

A second fecal sample was requested by the Parasitology laboratory (in order to reduce the risk of post-defecation contamination of the fecal samples with free-living larvae), and a sample was collected by the dog owner (directly after defecation) 7 days after the previous samples were collected and sent to the same laboratory.

The pooled fecal sample was examined at the Parasitology laboratory, NMBU, by various techniques for endoparasites. These include blending with water in a mechanical blender, sieving to remove large particulates, concentration by centrifugation, McMasters egg-counting technique, sucrose flotation on direct smears (mixing a drop of fecal concentrate with a drop of saturated sucrose on a microscope slide, applying a coverslip and, following a minute pause, focusing on the upper layer during microscopy), and an immunofluorescence antibody test (IFAT; staining with monoclonal antibodies against Giardia cyst walls and Cryptosporidium oocyst walls that are labelled with fluorescein isothiocyanate) for Cryptosporidium and Giardia infection. In addition, the sample was analysed by the Baermann technique for demonstration of lungworm larvae. Most of these techniques are standard methods in veterinary parasitology diagnostic laboratories, and have been conducted as routine methods in our laboratory for decades. More detailed descriptions of these techniques can be found in standard parasitology texts such as Deplazes et al. (2016).

On receipt of the second fecal sample, the same analyses were conducted as described above. In addition, a small amount (approximately pea-sized) of feces was placed on a blood agar dish, and incubated at room temperature (ca. $22^{\circ} \mathrm{C}$ ) for 3 days (Saari and Nikander, 2006), before microscopy examination at 100-400 times magnification.

\section{Case 2}

A litter of young piglets had refractory diarrhoea. Fresh fecal samples from four of the piglets were collected at the Ambulatory Clinic at NMBU and 
delivered to the Parasitology laboratory on the same campus as the clinic. The samples were examined by the same techniques for endoparasites as used in case 1, including McMasters egg-counting technique, sucrose flotation on sample concentrates and the IFAT for Cryptosporidium and Giardia infection. As nematodes were observed in two of the four direct smears, the samples were additionally analysed by the Baermann technique and culturing on blood agar plates as described for case 1. Followup samples were requested but could not be provided by the clinic.

\section{Molecular investigations for both cases}

DNA was isolated from the cultured material and from the larvae isolated from the Baermann test according to instructions in QIAamp DNA mini kit protocol for tissue (Qiagen $\mathrm{GmbH}$, Hamburg, Germany).

For both cases, the morphology indicated rhabditid nematodes. However, molecular confirmation and, if possible, identification of the genus, and, preferably, species was considered important. This is particularly so for possible Strongyloides infection, due to the zoonotic potential of $S$. stercoralis. A total of four different primers sets were used from previously published protocols (see Table 1). The PCR conditions used (times and temperatures for the different cycles) were those used in the original publications. For all reactions conducted, nanopure water was used as negative control and visualization of the PCR products was by $2 \%$ gel electrophoresis, using $\mathrm{SYBR}^{\circledR}$ safe as a stain (Invitrogen, NY, USA), and appropriate ladders for estimating the size of products.

Amplified DNA products were purified using (High Pure PCR purification kit, Roche Diagnostics GmbH, Mannheim, Germany) and the DNA sequenced in both directions at a commercial facility (GATC Biotech, Konstanz, Germany). All sequences obtained were compared with sequences in GenBank.

\section{Treatment and follow-up}

Case 1. Due to a suspicion of idiopathic eosinophilic bronchopneumonia, based on clinical findings, the dog was treated with prednisolone $\left[1 \mathrm{mg} \mathrm{kg}^{-1}\right.$ bodyweight (BW) once daily] (Clercx and Peeters, 2007). According to the owners, this had a positive effect on the dog's condition.

After the diagnosis of infection with a rhabditid nematode was confirmed, the dog was treated with fenbendazole $\left(50 \mathrm{mg} \mathrm{kg}^{-1} \mathrm{BW}\right.$ daily for 3 days, Panacur $^{\circledR}$, MSD Animal Health, Bergen, Norway) and selamectin $\left(6.5 \mathrm{mg} \mathrm{kg}^{-1} \mathrm{BW}\right.$ once; Spot-on, Stronghold $^{\circledR}$, Zoetis).

A follow-up fecal sample, examined 2.5 months after treatment for parasites, was negative, and the owner reported that the clinical signs had not recurred.

Case 2. Details of treatment and follow-up are not available.

\section{RESULTS}

\section{Case 1}

The dog appeared quiet with a normal temperature $\left(38.1^{\circ} \mathrm{C}\right)$, and a tendency to abdominal respiration, but with normal lung sounds on auscultation of the chest.

A haematology profile (Lacercyte ${ }^{\circledR}$ IDEXX) showed mild eosinophilia, $2.39 \times 10^{9} \mathrm{~L}^{-1}$, (reference range $0 \cdot 1-1 \cdot 49 \times 10^{9} \mathrm{~L}^{-1}$ ) but was otherwise within normal limits. Eosinophilia was confirmed by blood smear.

Bronchoscopy revealed no abnormalities in the larynx, trachea and main bronchi.

$\mathrm{X}$-ray of the thorax revealed a normal diaphragmatic couple, normal ribs and spine, and diffuse interstitial and moderate bronchial pattern of the lungs with normal sized heart.

Sediment from bronchoalveolar lavage demonstrated more than $50 \%$ eosinophils, some normal bronchial epithelial cells, and a few macrophages and neutrophils.

Table 1. PCR (target genes, expected product size and original reference) used in the molecular investigations in both case 1 (dog) and case 2 (piglets) and results achieved from electrophoresis of PCR product and sequencing where applicable

\begin{tabular}{|c|c|c|c|c|c|}
\hline \multirow{2}{*}{$\begin{array}{l}\text { Target gene and expected } \\
\text { product size }\end{array}$} & \multirow[b]{2}{*}{ References } & \multicolumn{2}{|l|}{$\mathrm{PCR}$ result } & \multicolumn{2}{|c|}{ Sequencing result } \\
\hline & & Case 1 & Case 2 & Case 1 & Case 2 \\
\hline $\begin{array}{l}\text { ITS1 region of the ribosomal DNA } \\
680 \mathrm{bp}\end{array}$ & $\begin{array}{l}\text { Ahmad et al. } \\
\text { (2013) }\end{array}$ & $\begin{array}{l}\text { Positive }- \\
\text { approx. } 680 \mathrm{bp}\end{array}$ & Not used & Contaminant & - \\
\hline $\begin{array}{l}\text { 18S ribosomal RNA, } 392 \text { and } 101 \\
\text { bp }\end{array}$ & $\begin{array}{l}\text { Sitta et al. } \\
\text { (2014) }\end{array}$ & Negative & Negative & $\begin{array}{l}\text { No PCR } \\
\text { product }\end{array}$ & $\begin{array}{l}\text { No PCR } \\
\text { product }\end{array}$ \\
\hline $18 \mathrm{~S}$ rDNA, $500 \mathrm{bp}$ & $\begin{array}{l}\text { Haber et al. } \\
(2005)\end{array}$ & $\begin{array}{l}\text { Positive }- \\
\text { approx. } 500 \mathrm{bp}\end{array}$ & $\begin{array}{l}\text { Positive }- \\
\text { approx. } 500 \mathrm{bp}\end{array}$ & $\begin{array}{l}\text { Pelodera } \\
\text { pseudoteres }\end{array}$ & Rhabditis axei \\
\hline SSU18A/SSU26R 1000 bp & $\begin{array}{l}\text { Floyd et al. } \\
\text { (2002) }\end{array}$ & $\begin{array}{l}\text { Positive }- \\
\text { approx. } 1000 \mathrm{bp}\end{array}$ & Not used & $P \cdot$ pseudoteres & - \\
\hline
\end{tabular}


Results from McMasters egg-counting technique, sucrose flotation on direct smears, and IFAT for Cryptosporidium and Giardia infection on the initial pooled sample were all negative.

Baermann investigation for lung worm revealed larvae of between 600 and $800 \mu \mathrm{M}$ length that did not resemble any of the more common lungworm larvae that may be identified in Norwegian dogs, such as Crenosoma vulpis (240-300 $\mu \mathrm{M})$, Angiostrongylus vasorum (310-400 $\mu \mathrm{M})$ and Oslerus osleri $(230-300 \mu \mathrm{M})$ (Deplazes et al. 2016). The larvae had the morphology consistent with rhabditid larvae (including the characteristic hourglass oesophagus).

As the same results were obtained with the second fecal sample as the first fecal sample, and the samples were collected directly after defecation, it seemed probable that the larvae had been passed in the dog feces and were not due to contamination of the samples. As larvae were found in different samples that had been collected a few days apart, it seemed unlikely that the larvae had been ingested and excreted, particularly as they were motile and did not appear to be digested/partially digested. However, this possibility could not be definitively excluded.

Despite the travel and contact history of the dog not being suggestive of $S$. stercoralis infection (which is not endemic in Norway), infection with $S$. stercoralis needed to be investigated, not least due to its zoonotic potential. Culturing on blood agar plates yielded a young nematode population resembling S. stercoralis (Fig. 1). However, careful measurement of the different stages and parts of the worms were not entirely consistent with $S$. stercoralis (Table 2).

A nested PCR targeting ITS1 region of the ribosomal DNA gene was used first (see Table 1). This PCR was originally published as a diagnostic tool for $S$. stercoralis infection in humans (Ahmad et al. 2013) and products of the expected size (approx. 680 base pairs) were obtained (Fig. 2) indicating that $S$. stercoralis infection seemed likely. However, sequencing of purified product indicated that the amplified DNA was that of a contaminant, with the closest match $(85 \%)$ being that of the oomycete, soilborne plant pathogen Phytophthora sojae. Repeated DNA isolation and PCR obtained the same result.

A further three PCRs were then attempted (see Table 1), one of which did not yield products of the expected size. However, DNA amplification was obtained with the third primer set used (Floyd et al. 2002), targeting the $5^{\prime}$ segment of the small subunit ribosomal RNA (SSU) gene, and developed for Rhabditida in general, with a product of the expected size (ca. $1000 \mathrm{bp}$ ). Sequencing and comparison with sequences in GenBank indicated a high degree of similarity (99\%) with Pelodera

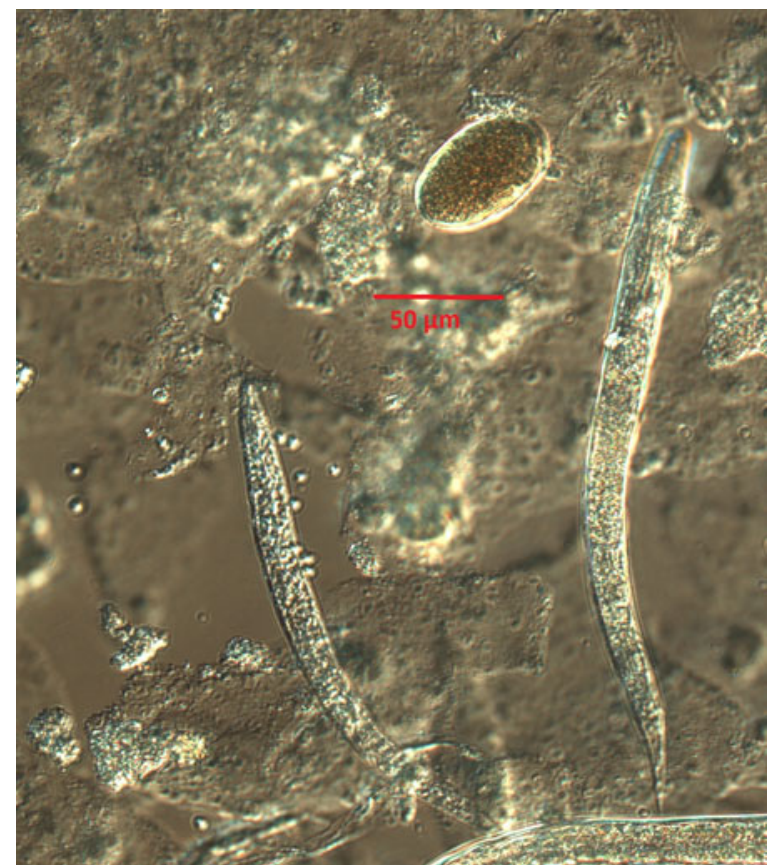

Fig. 1. Typical example of rhabditida population observed on microscopy of smears from blood agar culturing of the dog feces; larvae and eggs. Photograph taken on a Leica fluorescence microscope using Nomarski optics, at $\times 400$ magnification.

pseudoteres (GenBank Accession number EU196023.1) and $96 \%$ similarity with $P$. teres (GenBank Accession number: AF083002.1). This result concurs - with the measurements and observations made in the morphological studies presented in Table 2. However, lack of $100 \%$ identity implies that the results must be interpreted with caution. Similar results were obtained with primer pair described by Haber et al. (2005).

\section{Case 2}

Results from IFAT for Cryptosporidium and Giardia infection on all samples were negative; however, the McMasters egg-counting technique and sucrose flotation on direct smears revealed low numbers of Oesophagostomum eggs in two samples, and nematode larvae with rhabditid morphology measuring $280 \mu \mathrm{M}$ were detected in those samples. These two samples were also positive for nematode larvae of the same size using the Baermann technique.

Culturing of sub-samples of the feces on standard blood agar plates resulted in the development of populations of rhabditid nematodes from all four piglets (Fig. 3). Measurements are provided in Table 3.

Two different PCR investigations of the rhabditid nematodes isolated from the piglet samples were attempted (Table 1). A PCR product of the expected size was obtained from one PCR (Haber et al. 2005). Comparison of the sequence obtained with those in 
Table 2. Measurements (in $\mu \mathrm{M}$ ) from morphometric studies of nematodes obtained from blood agar culture of dog samples as compared with measurements reported for Strongyloides stercoralis (free-living generation), Pelodera teres and Pelodera pseudoteres

\begin{tabular}{|c|c|c|c|c|c|}
\hline & \multirow[b]{2}{*}{$\begin{array}{l}\text { Sample results, case } 1 \\
\text { Measurements (in } \mu \mathrm{M})\end{array}$} & \multicolumn{2}{|c|}{ Strongyloides stercoralis } & \multirow[b]{2}{*}{ Pelodera teres ${ }^{\mathrm{c}}$} & \multirow[b]{2}{*}{$\begin{array}{l}\text { Pelodera } \\
\text { Pseudoteres }^{\mathrm{c}}\end{array}$} \\
\hline & & $\begin{array}{l}\text { Various } \\
\text { webpages }^{\text {a }}\end{array}$ & $\begin{array}{l}\text { Published } \\
\text { case }^{\mathrm{b}}\end{array}$ & & \\
\hline Adults & $\operatorname{Max}-\min ($ mean $) N=10$ & \multicolumn{2}{|c|}{ Measurements (in $\mu \mathrm{M}$ ) } & \multicolumn{2}{|c|}{ Measurements (in $\mu \mathrm{M}$ ) } \\
\hline \multirow[t]{2}{*}{ Body length adults } & $\mathrm{F}-1350-1950(1598)$ & $F-1000-1700$ & $\begin{array}{l}\text { F795-1045 } \\
(913)\end{array}$ & $\begin{array}{l}F-1165-1688 \\
(1337)\end{array}$ & $\begin{array}{l}F-797-1013 \\
(1005)\end{array}$ \\
\hline & $\mathrm{M}-1190-1450$ (1303) & $\mathrm{M}-700-1000$ & $\begin{array}{l}\mathrm{M}-617-685 \\
(655)\end{array}$ & $\begin{array}{l}\mathrm{M}-810-1085 \\
(922)\end{array}$ & $\begin{array}{l}\mathrm{M}-688-968 \\
(778)\end{array}$ \\
\hline \multirow[t]{2}{*}{ Body width } & $F-78-133(102)$ & $F-50-75$ & $F-42-67(56)$ & $F-68-108(95)$ & $F-54-67(61)$ \\
\hline & $\mathrm{M}-50-98(73)$ & $M-40-50$ & $M-30-43(38)$ & $M-49-69(56)$ & $\mathrm{M}-47-65(54)$ \\
\hline \multirow[t]{2}{*}{ Buccal cavity length } & $\mathrm{F}-23-35(27)$ & Short & Very short & $F-26-29(28)$ & $F-27-31(29)$ \\
\hline & $M-23-25(24)$ & Short & Very short & $M-23-30(25)$ & $M-23-29(34)$ \\
\hline \multirow[t]{2}{*}{ Oesophagus length } & $F-206-256(235)$ & & $\begin{array}{l}F-110-152 \\
(123)\end{array}$ & & \\
\hline & M - 188-221 (204) & & $\begin{array}{l}\mathrm{M}-110-123 \\
(113)\end{array}$ & & \\
\hline \multirow{2}{*}{$\begin{array}{l}\text { L1-L3 larvae } \\
\text { Length, } \mathrm{L}_{1} / \mathrm{L}_{2} / \mathrm{L} 3\end{array}$} & & & & & \\
\hline & $\mathrm{L}_{2}-600$ (from feces) & $\begin{array}{l}\mathrm{L}_{1}-180-380 \\
\text { width } 60 \\
\mathrm{~L}_{2}-440 \\
\mathrm{~L}_{3}-350-600 \\
\text { width } 50\end{array}$ & $\begin{array}{l}347-460(412) \\
\text { width } 22-35 \\
(26)\end{array}$ & $\begin{array}{l}\mathrm{L}_{3}-365-464 \\
(406)\end{array}$ & $\begin{array}{l}\mathrm{L}_{3}-439-545 \\
(499)\end{array}$ \\
\hline Tail length & $F-30-75(45)$ & & & $F-50-63(59)$ & $F-36-48(44)$ \\
\hline Spicule length & $40-60(53)$ & & $37-40(39)$ & $40-45(42)$ & $36-48(42)$ \\
\hline Eggs & $\operatorname{Max}-\min ($ mean $) N=22$ & & & & \\
\hline Length $\times$ width & $55-70 \times 35-45(64 \times 39)$ & $50-60 \times 30-35$ & $\begin{array}{l}40-43 \times 25-30 \\
(42 \times 27)\end{array}$ & $\begin{array}{l}50-54 \times 29-32 \\
(51 \times 33)\end{array}$ & $\begin{array}{l}54-81 \times 32-38 \\
(67 \times 37)\end{array}$ \\
\hline
\end{tabular}

${ }^{a}$ Webpages used: Merck Veterinary Manual http://www.merckvetmanual.com/mvm/index.html; Parasitipedia, http:// parasitipedia.net/index.php?option=com_content\&view=article\&id=2612\&Itemid=2928; College of Veterinary Medicine, Iowa State University, http://vetmed.iastate.edu/.

b As reported by Hong et al. (2009).

c As reported by Schulte (1989).

M, Male; F, female.

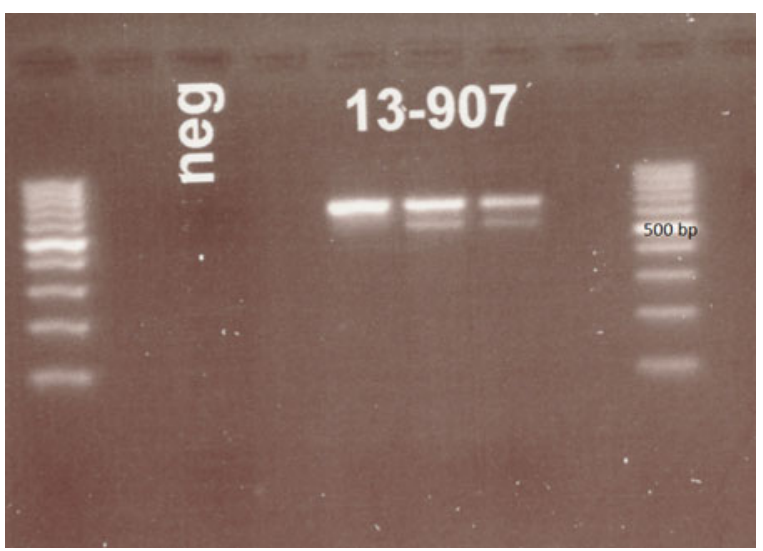

Fig. 2. Gel picture following electrophoresis of DNA products after PCR targeting the ITS1 region of the ribosomal DNA of Strongyloides stercoralis using primers described by Ahmad et al. (2013). Clear bands at about $680 \mathrm{bp}$ are seen for each sample. Ladders are provided at each side of the image. The three columns labelled 13-907 represent PCR results from three consecutive samples.

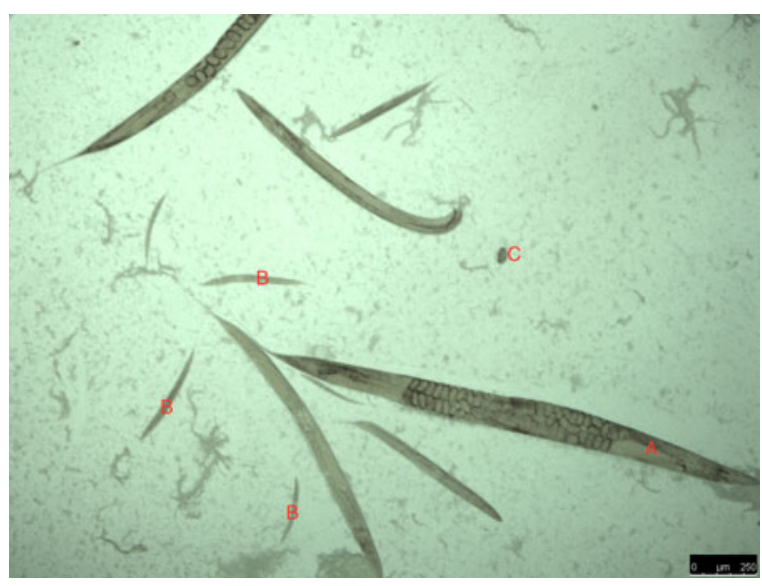

Fig. 3. Typical example of rhabditida population observed on microscopy of smears from blood agar culturing of the piglet feces; adults (A), larvae (B) and eggs (C). 
Table 3. Measurements from morphometric studies from blood agar culture from piglet samples as compared with those reported for Strongyloides ransomi (free-living generation) and Rhabditis axei

\begin{tabular}{|c|c|c|c|}
\hline & $\begin{array}{l}\text { Sample results, case } 2 \\
\text { Measurements (in } \mu \mathrm{M} \text { ) Max-min } \\
\text { (mean) }\end{array}$ & $\begin{array}{l}\text { Strongyloides ransom } i^{\mathrm{a}} \\
\text { Measurements (in } \mu \mathrm{M} \text { ) }\end{array}$ & Rhabditis axei ${ }^{\mathrm{b}}$ \\
\hline Adults & $\mathrm{F}-N=20 ; \mathrm{M}-N=16$ & & \\
\hline Body length & $\begin{array}{l}\mathrm{F}-1270-1630(1414), \mathrm{M}-800-1160 \\
(1020)\end{array}$ & $\begin{array}{l}\mathrm{F}-1000-1100, \mathrm{M}-868- \\
899\end{array}$ & $\begin{array}{l}\mathrm{F}-1400-1800, \mathrm{M}-900- \\
1550\end{array}$ \\
\hline Body width & $\mathrm{F}-45-100(74), \mathrm{M}-38-68(53)$ & $\mathrm{F}-62, \mathrm{M}-54$ & $\mathrm{~F}-100, \mathrm{M}-60$ \\
\hline $\begin{array}{l}\text { Buccal cavity } \\
\text { length }\end{array}$ & $\mathrm{F}-25-33(29), \mathrm{M}-23-30(27)$ & $\mathrm{F}-$ short, $\mathrm{M}-$ short & $\mathrm{F}-33$ \\
\hline Oesophagus length & F - 201-236 (219), M - 191-206 (199) & $\mathrm{F}-125-155, \mathrm{M}-132-140$ & $F-250-300$ \\
\hline Tail length & $\mathrm{F}-280-490(387), \mathrm{M}-210-250$ & $F-150-158$ & $\begin{array}{l}\mathrm{F}-650-850, \text { Males not } \\
\text { included }\end{array}$ \\
\hline Spicule length & $38-50(44)$ & $26-29$ & $50-65$ \\
\hline L1 larvae & $\operatorname{Max}-\min ($ mean $) N=10$ & & \\
\hline $\mathrm{L}_{1}$ - body length & $246-294(270)$ & $280-400$ & \\
\hline $\begin{array}{l}\text { Buccal cavity } \\
\text { length }\end{array}$ & & $5-6$ & \\
\hline Eggs & $\operatorname{Max}-\min ($ mean $) N=20$ & & \\
\hline Length $\times$ width & $48-63 \times 25-33(54-30)$ & $40-45 \times 20-35$ & 60 (length only) \\
\hline
\end{tabular}

a As reported by Schwartz (1930).

b As reported by Rakhshanpour (2012).

M, Male; F, female.

GenBank indicated a high degree of similarity (99\%) with Rhabditis (Rhabditella) axei (GenBank Accession Nr AY284654.1). Again, a lack of 100\% identity implies that the results must be interpreted with caution.

\section{DISCUSSION}

In this paper, we describe two unrelated cases of apparent infection with rhabditid nematodes diagnosed in a dog and in piglets in Norway. Neither of the infections were Strongyloides spp., although in both cases the identification of rhabditid larvae in fecal samples from symptomatic animals immediately suggested the possibility of Strongyloides infections. Correct identification of Strongyloides infections is of particular relevance due to the potential for zoonotic transmission of $S$. stercoralis. Although sample contamination with free-living nematodes following deposition of the feces on the ground cannot be entirely excluded, as the dog samples were collected by the owner immediately after defecation and larvae were found in samples from different days (repeat sampling) it seems likely that the nematodes were from the fecal samples themselves, rather than from environmental contamination. However, for the piglet samples, for which follow-up samples were not available, the uncertainty is greater.

Among the plethora of Rhabditida, intestinal infections of dogs have been almost exclusively associated with $S$. stercoralis, and therefore this diagnosis was foremost under consideration when the rhabditida morphology was first observed, and PCR results (without sequencing) indicated the amplification of a DNA sequence of the correct size. However, although cases of $S$. sterocoralis in dogs have been reported from Norway previously (Hamnes et al. 2009), this has been associated with imported dogs. Furthermore, although Strongyloides infection in dogs has been reported from a range of European countries, including Italy (Riggio et al. 2013), Romania (Mircean et al. 2012), Greece (Papazahariadou et al. 2007), Germany (Epe et al. 2004), Slovakia (Totková et al. 2006) and Finland (Dillard et al. 2007), in all these cases either the environmental conditions are suitable for supporting transmission of infection, or the dogs have been imported or had contact with imported dogs. In the current case, the lack of an obvious plausible source of infection and transmission route raised doubts about the validity of the infection being $S$. stercoralis, and these doubts were supported by both sequencing results from the first PCR, lack of amplification from other PCR, and morphometric considerations.

Our results demonstrate that it is important that diagnosticians do not jump to conclusions too rapidly based on what has been previously reported, especially with regard to unusual or unexpected infections. In addition, when molecular methods are used for screening or confirmation of morphological findings, there should also be awareness of the possibility of unexpected amplification of other co-isolated DNA, which may result in confounding results. Sequencing of PCR products provides the only way to be certain that the amplified DNA product is that which it is assumed to be. 
Although Pelodera larvae were isolated from the dog fecal samples taken 1 week apart, suggesting that post-defecation contamination of samples from the environment or simple carriage of the nematodes from ingestion of contaminated material (such as due to coprophagia) are unlikely, neither of these possibilities can be entirely excluded. The clinical picture, including mild eosinophilia and improvement in clinical signs following treatment, also support this being an actual infection with clinical signs resulting. Pelodera pseudoteres is generally thought to be a free-living species not known to be infectious to animals. However, it tolerates highly saprophytic anaerobic conditions, such as are found in fermenting compost and manure, and could be easily ingested by dogs and survive in the gut for some time. According to Anderson and Coleman (1982) the optimal growth temperature for Pelodera is $20-30{ }^{\circ} \mathrm{C}$, but it can also survive for 5 days in $37^{\circ} \mathrm{C}$. Results from some preliminary survival investigations (data not provided) with the samples described in the current paper at our laboratory demonstrated the survival of these $P$. pseudoteres cultures at $37^{\circ} \mathrm{C}$ for at least 3 days.

As the morphometric measurements presented in Table 2 show, the adults of the Pelodera species isolated from the dog feces in this case were considerably larger than $P$. pseudoteres described by Schulte (1989). Females were 50\% longer and males almost twice the size of Schulte's isolates. Almost all parameters are higher and correspond better with morphometric data for a closely related species, $P$. teres. Measurements show that free-living individuals of $S$. stercoralis are generally a little smaller, but the size of eggs and larvae can be confusing due to the overlap between species. The size of Pelodera cultivated in the laboratory is very much dependent on abundance of food and age of the culture (Schulte, 1989). Individuals taken for measurements early were much larger than those from old colonies approaching the stationary growth phase. This could explain differences with literature data, but could also indicate a different strain or even subspecies.

Another interesting aspect of this case is that only respiratory signs (forced respiration but no cough) were reported and there were no signs of gastrointestinal disease. It is quite possible that the respiratory signs were unrelated to the Pelodera, and, indeed, for rhabditid infections in general, this would be a rather unusual presentation. Canine Strongyloides infections generally present with abdominal problems in puppies (Dillard et al. 2007), although diarrhoea is not always present in adult dogs. Canine Pelodera infections usually present as dermatitis. One possible explanation could be that this infection resulted in an eosinophilic bronchopneumonia, which together with strenuous exercise (when hunting) caused dyspnoea. However, this is highly speculative. The clinical signs appeared to resolve following the initial immunosuppressive doses of prednisolone, prior to the specific treatment. Although it is not possible to be certain about the specific cause of the dyspnoea, it is possible that Pelodera in the intestinal tract caused or exacerbated any inflammation.

Rhabditis axei is a common nematode in decomposing organic matter in water and in soils, and although it is not generally considered parasitic, some reports in the literature indicate that parasitic lifecycles may occur (Rakhshanpour et al. 2012). This species has been cultured routinely on agar plates and has a relatively high optimal growth temperature of $37^{\circ} \mathrm{C}$ (Anderson and Coleman, 1982; Hayat et al. 1999). This suggests that, considered from a temperature-perspective, this species is likely to survive as an endoparasite or commensal in mammals.

Although we were unable to identify any publications describing the isolation of $R$. axei from pig samples, Roepstorff et al. (1998) when investigating parasitic status of pig farms observed eggs resembling rhabditid eggs (Strongyloides was suggested but not confirmed) in freshly collected feces. As shown in Table 3, the dimensions of the Strongyloides and Rhabditis eggs overlap, as do the dimensions of the larvae. As stated by Hong et al. (2009) and other authors, free-living forms of Strongyloides resemble Rhabditis sp. and therefore careful analysis is necessary to distinguish between them.

In our case, the presence of $R$. axei in feces from piglets with diarrhoea was confirmed by both morphological and molecular investigations. The route of infection is unknown, but it would seem probable that oral contact with organic matter decomposing on the floor could represent a hygiene hazard. The lactogenic route cannot be excluded, but there is no support for this transmission scenario as the adult pigs were not examined. However, as with all such cases, despite repeat samples and multiple samples from different piglets, post-defecation contamination of the samples cannot be totally excluded.

In conclusion, diagnosticians in the Veterinary Parasitology laboratory should be aware that rhabditid larvae found on Baermann examination need not necessarily indicate infection with Strongyloides spp., even if the same larvae are detected in more than one specimen (thus suggesting real infection rather than post-defecation sample contamination or carriage rather than establishment of infection). Careful measurements should be made when morphological observations are being made of cultures from agar. If molecular confirmation is sought, then a positive PCR result, even when the product size is as expected, should be supported by sequencing. 


\section{FINANCIAL SUPPORT}

This research received no specific grant from any funding agency, commercial or not-for-profit sectors. Referring veterinarians are invoiced for diagnostic services at $\mathrm{NMBU}$, and the veterinarian bills the animal owner.

\section{CONFLICTS OF INTEREST}

None.

\section{REFERENCES}

Ahmad, A. F., Hadip, F., Ngui, R., Lim, Y. A. and Mahmud, R. (2013). Serological and molecular detection of Strongyloides stercoralis infection among an Orang Asli community in Malaysia. Parasitology Research 112, 2811-2816.

Anderson, R. V. and Coleman, D. C. (1982). Nematode temperature responses: a niche dimension in populations of bacterial-feeding nematodes. Fournal of Nematology 14, 69-76.

Campos, D. M., Araújo, J. L., Vieira, M. C., Damasceno, F. and Barbosa, A. P. (2002). A case of parasitism by Rhabditis sp in a child from Goiânia, Goiás, Brazil. Revista da Sociedade Brasileira de Medicina Tropical 35, 519-522.

Carta, L. K., Handoo, Z. A., Lebedeva, N. I., Raina, A. K., Zhuginisov, T. I. and Khamraev, A. Sh. (2010). Pelodera termitis sp.n. and two other rhabditid nematode species associated with the Turkestan termite Anacanthotermes turkenistanicus from Uzbekistan. International Fournal of Nematology 20, 125-134.

Casanova, J. C., Arrizabalaga, A., Spakulova, M. and Morand, S. (1996). The first record of Rhabdias (Pelodera) orbitalis (Nematoda: Rhabditidae), a larval parasite in the eyes of the rodent Chionomys nivalis on the Iberian Peninsula. Helmintologica 33, 227-229.

Clercx, C. and Peeters, D. (2007). Canine eosinophilic bronchopneumopathy. Veterinary Clinics of North America: Small Animal Practice 37, 917-935.

Deplazes, P., Eckert, J., Mathis, A., von Samson-Himmelstjerna, G. and Zahner, H. (2016). Parasitology in Veterinary Medicine, pp. 650 Wageningen Academic Publishers, Wageningen, Netherlands.

Dillard, K. J., Saari, S. A. and Anttila, M. (2007). Strongyloides stercoralis infection in a Finnish kennel. Acta Veterinaria Scandinavica 49, 37.

Duarte, E. R., Melo, M. M. and Hamdan, J. S. (2001). Epidemiological aspects of bovine parasitic otitis caused by Rhabditis spp. and/or Raillietia spp. in the state of Minas Gerais, Brazil. Veterinary Parasitology 101, 45-52. el-Azazy, O. M., el-Gawady, H. M. and Nada, M. S. (1988). The occurrence of Rhabditis (Rhabditella) axei in the faeces of a chicken in Egypt. Fournal of Helminthology 62, 219-220.

Epe, C., Coati, N. and Schnieder, T. (2004). Results of parasitological examinations of faecal samples from horses, ruminants, pigs, dogs, cats, hedgehogs and rabbits between 1998 and 2002. Deutsche Tierärztliche Wochenschrift 111, 243-247.

Floyd, R., Abebe, E., Papert, A. and Blaxter, M. (2002). Molecular barcodes for soil nematode identification. Molecular Ecology 11, 839-850

Haber, M., Schüngel, M., Putz, A., Müller, S., Hasert, B. and Schulenburg, H. (2005). Evolutionary history of Caenorhabditis elegans inferred from microsatellites: evidence for spatial and temporal genetic differentiation and the occurrence of outbreeding. Molecular Biology and Evolution 22, 160-173.

Hamnes, I. S., Davidson, R. and Øines, Ø. (2009). Strongyloides stercoralis påvist hos hund i Norge for første gang. [Strongyloides stercoralis identified in dogs in Norway for the first time]. Norsk Veterincertidsskrift 121,752 .

Hayat, C. S., Akhtar, M., Qudoos, A., Badar, N. and Hayat, B. (1999). Some observations on the subculturing of Rhabditis axei (Nematoda). Indian Veterinary fournal 76, 202-204.

Hong, Y.-H., Kim, Y.-W., Rheem, I.-S., Kim, J.-S., Kim, S.-B., Chai, Y.-Y., Guk, S.-M., Lee, S.-H. and Seo, M. (2009). Observation of the free-living adults of Strongyloides stercoralis from a human stool in Korea. Infection and Chemotherapy 41, 105-108.

Jones, C. C., Rosen, T. and Greenberg, C. (1991). Cutaneous larva migrans due to Pelodera strongyloides. Cutis 48, 123-126.

Lukeš, S., Prokopič, J. and Hulinska, D. (1982). Morphological study of Pelodera teres Schneider, 1866 by scanning electron microscopy. Folia Parasitologica 29, 33-36.

Meamar, A. R., Kia, E. B., Zahabiun, F., Jafari-Mehr, A., Moghadam, A. and Sadjjadi, S. M. (2007). The occurrence of severe infections with Rhabditis axei in AIDS patients in Iran. Fournal of Helminthology 81, 351-352.

Mircean, V., Györke, A. and Cozma, V. (2012). Prevalence and risk factors of Giardia duodenalis in dogs from Romania. Veterinary Parasitology 184, 325-329.

Papazahariadou, M., Founta, A., Papadopoulos, E., Chliounakis, S., Antoniadou-Sotiriadou, K. and Theodorides, Y. (2007). Gastrointestinal parasites of shepherd and hunting dogs in the Serres Prefecture, Northern Greece. Veterinary Parasitology 148, 170-173.

Rakhshanpour, A., Youssefi, M. R., Marhaba, Z., Aryaiepour, M., Mobedi, I., Kia, E. B. and Rahimi, M. T. (2012). The morphological and morphometric study of Rhabditis axei from Atherurus macrourus (Asiatic brush-tailed porcupine). Global Veterinaria 8, 305-307.

Ramos, J. J., Luco, D. F., Verde, M. T., Lucientes, J. and Fernández, A. (1996). Pelodera dermatitis in sheep. Veterinary Record 138, 474-475.

Rashmir-Raven, A. M., Black, S. S., Rickard, L. G. and Akin, M. (2000). Papillomatous pastern dermatitis with spirochetes and Pelodera strongyloides in a Tennessee Walking Horse. Fournal of Veterinary Diagnostic Investigation 12, 287-291.

Riggio, F., Mannella, R., Ariti, G. and Perrucci, S. (2013). Intestinal and lung parasites in owned dogs and cats from central Italy. Veterinary Parasitology 193, 78-84.

Roberts, L. S. and Janovy, J. (2005). Nematodes: Rhabditida, pioneering parasites. In Foundations of Parasitology (ed. Schmidt, G. D. and Roberts, L. S.), pp. 411-416. McGraw-Hill, New York, USA.

Roepstorff, A., Nilsson, O., Oksanen, A., Gjerde, B., Richter, S. H., Ortenberg, E., Christensson, D., Martinsson, K. B., Bartlett, P. C., Nansen, P., Eriksen, L., Helle, O., Nikander, S. and Larsen, K. (1998). Intestinal parasites in swine in the Nordic countries: prevalence and geographical distribution. Veterinary Parasitology 76, 305-319.

Saari, S. A. and Nikander, S. E. (2006). Pelodera (syn. Rhabditis) strongyloides as a cause of dermatitis - a report of 11 dogs from Finland. Acta Veterinaria Scandinavica 48, 18

Schulte, F. (1989). Description of Rhabditis (Pelodera) pseudoteres n. sp. (Rhabditidae: Nematoda) with a redescription of its sibling $R .(P$.$) teres$ (Schneider, 1866). Revue de Nématologie 12, 387-394.

Schwartz, B. (1930). Species of the nematode genus Strongyloides parasitic in domestic swine. Fournal of Agricultural Research 40, 11-23.

Sitta, R. B., Malta, F. M., Pinho, J. R., Chieffi, P. P., Gryschek, R. C. B. and Paula, F. M. (2014). Conventional PCR for molecular diagnosis of human strongyloidiasis. Parasitology 141, 716-721.

Sudhaus, W., Schulte, F. and Homonick, W. M. (1987). A further sibling species of Rhabditis (Pelodera) strongylides (Nematoda): Rhabditis $(P$.) cutanea sp. $\mathrm{n}$. from the skin of wood mice Apodemus silvaticus. Revue de Nématologie 10, 319-326.

Tanaka, A., Kinoshita, M., Tanaka, T., Iwanaga, Y., Kagei, N. and Hide, M. (2004). Pelodera strongyloides infestation presenting as pruritic dermatitis. Fournal of the American Academy of Dermatology 51(5 Suppl.), S181-S184.

Teschner, M., Würfel, W., Sedlacek, L., Suerbaum, S., Tappe, D. and Hornef, M. W. (2014). Outer ear canal infection with Rhabditis sp. nematodes in a human. Fournal of Clinical Microbiology 52, 1793-1795.

Totková, A., Klobusický, M., Holková, R. and Friedová, L. (2006). Current prevalence of toxocariasis and other intestinal parasitoses among dogs in Bratislava. Epidemiologie, Mikrobiologie, Imunologie: casopis Spolecnosti pro epidemiologii a mikrobiologii Ceské lékarské spolecnosti $\mathcal{F} . E$. Purkyne 55, 17-22.

Willers, W. B. (1970). Pelodera strongyloides in association with canine dermatitis in Wisconsin. Fournal of the American Veterinary Medical Association 156, 319-320. 